\title{
Analysis of the microRNA expression profile of normal human dermal papilla cells treated with $5 \alpha$-dihydrotestosterone
}

\author{
MYUNG JOO LEE ${ }^{1 *}$, HWA JUN CHA ${ }^{1 *}$, KYUNG MI LIM $^{1}$, OK-KYU LEE ${ }^{1}$, SEUNGHEE BAE ${ }^{1}$, \\ CHUN-HO KIM ${ }^{2}$, KEE-HO LEE $^{2}$, YU NA LEE $^{3}$, KYU JOONG AHN $^{3}$ and SUNGKWAN AN ${ }^{1}$ \\ ${ }^{1}$ Korea Institute for Skin and Clinical Sciences and Molecular-Targeted Drug Research Center, \\ Konkuk University, Seoul 143-701; ${ }^{2}$ Korea Institute of Radiological and Medical Sciences, Seoul 139-706; \\ ${ }^{3}$ Department of Dermatology, Konkuk University School of Medicine, Seoul 143-729, Republic of Korea
}

Received June 13, 2014; Accepted February 24, 2015

DOI: $10.3892 / \mathrm{mmr} .2015 .3478$

\begin{abstract}
Clinical evidence has demonstrated that the accumulation of $5 \alpha$-dihydrotestosterone (DHT) in dermal papilla cells (DPCs) is implicated in androgenetic alopecia. Whether this accumulation in DHT may have direct cellular effects leading to androgenetic alopecia remains to be elucidated. The present study aimed to determine whether DHT affects cell growth, cell cycle arrest, cell death, senescence and the induction of reactive oxygen species (ROS), and whether these effects are mediated by microRNA (miRNA)-dependent mechanisms. The cell viability and cell cycle were determined, levels of ROS were examined and senescence-associated $\beta$-galactosidase assays were performed in normal human DPCs (nHDPCs). Furthermore, miRNA expression profiling was performed using an miRNA microarray to determine whether changes in the expression levels of miRNA were associated with the cellular effects of DHT. The results revealed that DHT decreased cell growth by inducing cell death and G2 cell cycle arrest, and by increasing the production of ROS and senescence in the nHDPCs. In addition, 55 miRNAs were upregulated and 6 miRNAs were downregulated inthe DHT-treated nHDPCs. Bioinformatic analysis demonstrated that the putative target genes of these upregulated and downregulated miRNAs were involved in cell growth, cell cycle arrest, cell death, senescence and the production of ROS. Specifically, the target genes of five highly upregulated and downregulated miRNAs were identified and were associated with the aforementioned effects of DHT. These results
\end{abstract}

Correspondence to: Professor Sungkwan An, Korea Institute for Skin and Clinical Sciences and Molecular-Targeted Drug Research Center, Konkuk University, 120 Neungdong-ro, Gwangjin-gu, Seoul 143-701, Republic of Korea

E-mail: ansfgrc@konkuk.ac.kr

*Contributed equally

Key words: 5 $\alpha$-dihydrotestosterone, human dermal papilla cell, microRNA demonstrated that the expression of miRNA was altered in the DHT-treated nHDPCs and suggest the potential mechanisms of DHT-induced cell growth repression, cell cycle arrest, cell death, senescence and induction of ROS.

\section{Introduction}

The $5 \alpha$-dihydrotestosterone (DHT) androgen is produced primarily by $5 \alpha$-reductase in the testes (1). DHT regulates male reproductive development, testes formation, growth of skeletal muscle and hair growth, through activation of the androgen receptor (2). The affinity of DHT is 10 -fold greater than that of teststerone for the androgen receptor, and leads to its hyperactivation, which induces shortening of the anagen phase of hair follicle growth (3-5).

The hair growth cycle is modulated predominantly by dermal papilla cells (DPCs), which are mesenchymal cells located at the base of hair follicles, regulating formation of the hair follicle and hair growth cycle through secretion of growth factors and cytokines (6-11). Previous studies have demonstrated that DHT inhibits protein kinase $\mathrm{C}$, regulates of the expression of B-cell lymphoma 2 (bcl-2)/blc-2-associated x protein (bax), and upregulates the expression of dickkopf 1 in the DPCs, leading to cell apoptosis, shortening of the hair cycle, a reduction in hair growth, and hair loss (12-14).

MicroRNAs (miRNAs) are a class of small ( 22 nt) noncoding RNAs, which bind to mRNAs in a sequence-specific manner to regulate the translation of target genes $(15,16)$. miRNAs are important in development, apoptosis and cell growth (17). Various studies have been performed to investigate the role of miRNAs in dermal papilla cells from the balding and non-balding scalp (14). In addition, investigations using mice, in which Dicer, a key enzyme of miRNA metabolism, has been knocked out, have revealed that miRNAs are essential for the morphogenesis and maintenance of hair follicles (18).

However, although DHT is well known as a key regulator of balding and hair follicle morphogenesis, DHT-dependent alterations of the miRNA expression profile and putative mechanisms remain to be elucidated. The present study investigated the cellular effects of DHT and the miRNA expression prolife in normal human DPCs (nHDPCs). 


\section{Materials and methods}

Cells and culture conditions. The nHDPCs were purchased from Innoprot (Biscay, Spain) and were cultured in Dulbecco's modified Eagle's medium (DMEM; Gibco, Life Technologies, Grand Island, NY, USA), supplemented with $10 \%$ fetal bovine serum (FBS; Sigma-Aldrich, St. Louis, MO, USA) and $1 \%$ penicillin/streptomycin at $37^{\circ} \mathrm{C}$ in a humidified atmosphere with $5 \% \mathrm{CO}_{2}$.

Cell viability assay. The viability of the nHDPCs was measured using a water-soluble tetrazolium salt (WST-1) assay (EZ-Cytox Cell Viability Assay kit; Itsbio, Seoul, Korea). For the cell viability assay, the nHDPCs were plated at a density of $5 \times 10^{3}$ cells/well in 96-well plates. After $24 \mathrm{~h}$, the cells were treated with doses of DHT between 0 and $1 \mathrm{mM}$ at $37^{\circ} \mathrm{C}$ for 24,48 , or $72 \mathrm{~h}$. The cells were then incubated with WST-1 reagent at $37^{\circ} \mathrm{C}$ for $30 \mathrm{~min}$, and the optical density was determined at $450 \mathrm{~nm}$ using a microplate reader (iMark; Bio-Rad Laboratories, Inc., Hercules, CA, USA).

Cell cycle assay. A propidium iodide (PI) staining-based cell cycle assay was performed using standard procedures, as described previously (10). The nHDPCs $\left(2 \times 10^{6}\right)$ were plated in $60 \mathrm{~mm}$ culture dishes and treated with DHT for $24 \mathrm{~h}$. The cells were then trypsinized with $0.25 \%$ Trypsin-EDTA (Gibco Life Technologies) at $37^{\circ} \mathrm{C}$, pelleted, washed with phosphate-buffered saline (PBS), and fixed with $70 \%$ ethanol at $4^{\circ} \mathrm{C}$ for $3 \mathrm{~h}$. The DNA in the fixed cells was stained using staining solution containing $50 \mu \mathrm{g} / \mathrm{ml}$ PI (Sigma-Aldrich), $0.5 \%$ Triton X-100 (Bioshop, Burlington, ON, Canada), and $100 \mu \mathrm{g} / \mathrm{ml}$ RNase (Bioshop) at $37^{\circ} \mathrm{C}$ for $1 \mathrm{~h}$. Following staining, the cells were analyzed using a FL2 channel with an excitation wavelength of $488 \mathrm{~nm}$ and an emission wavelength of $578 \mathrm{~nm}$, on a FACSCaliber flow cytometer (BD Biosciences, San Jose, CA, USA).

Reactive oxygen species (ROS) measurement. The measurement of ROS was performed, as previously reported, using 2',7'-dichlorofluorescein diacetate(DCF-DA) (19). The nHDPCs $\left(2 \times 10^{6}\right)$ were plated in $60 \mathrm{~mm}$ culture dishes and treated with DHT at $37^{\circ} \mathrm{C}$ for 24 h. 2', 7'-Dichlorodihydrofluorescin diacetate (DCF-DA; $20 \mu \mathrm{M}$ ) was added to the culture medium, and the cells were incubated at $37^{\circ} \mathrm{C}$ for $1 \mathrm{~h}$. The cells were then trypsinized with $0.25 \%$ Trypsin-EDTA at $37^{\circ} \mathrm{C}$, pelleted, washed with PBS, and analyzed using a FL1 channel with an excitation wavelength of $488 \mathrm{~nm}$ and an emission wavelength of $530 \mathrm{~nm}$ on a FACSCaliber flow cytometer (BD Biosciences).

Senescence-associated $\beta$-galactosidase (SA- $\beta$-gal) assay. For the detection of senescent cells, an SA- $\beta$-gal assay was performed, as previously described (20). Briefly, the nHDPCs $\left(2 \times 10^{6}\right)$ were plated in $60 \mathrm{~mm}$ culture dishes and treated with DHT at $37^{\circ} \mathrm{C}$ for $24 \mathrm{~h}$. The cells were then fixed with Fixative Solution (Senescence Detection kit; Biovision, Milpitas, CA, USA) and stained using a Staining Solution mix (Senescence Detection kit) supplemented with X-gal at $37^{\circ} \mathrm{C}$ for $24 \mathrm{~h}$. Images of the SA- $\beta$-gal-stained cells were captured using a camera mounted to a light microscope (CKX41; Olympus Corporation, Tokyo, Japan), and the number of stained cells were counted in five randomly selected microscopic fields from each condition.

miRNA microarray. The RNA in the cells was isolated using TRIzol reagent (Gibco Life Technologies), according to the manufacturer's instructions. The RNA integrity was evaluated using an Agilent 2100 Bioanalyzer (Agilent Technologies, Santa Clara, CA, USA), and the RNA quality was evaluated using spectrophotometry at the $260 / 280 \mathrm{~nm}$ ratio (Ultrospec 2100 Pro UV-Vis; Amersham Biosciences, GE Healthcare Life Sciences, Piscataway, NJ, USA). Samples with an RNA integrity score $>7.8$ and an RNA quality score $>2.0$ were used for the microarray. A total of 100 ng RNA was labeled with cyanine dye ( $\mathrm{Cy} 3)$ using an Agilent miRNA labeling kit (Agilent Technologies). The labeled RNAs were purified using Micro Bio-Spin P-6 columns (Bio-Rad Laboratories, Inc.) and hybridized using a SurePrint G3 Human v16 miRNA Microarray kit (8x60 K; Release 16.0; Agilent Technologies) at $65^{\circ} \mathrm{C}$ for $20 \mathrm{~h}$. The microarray was scanned using an Agilent microarray scanner (Agilent Technologies), and the images were analyzed using Agilent Feature Extraction version 10.7 software (Agilent Technologies). The digitized data were analyzed and the fold change was determined using GeneSpring GX version 11.5 software (Agilent Technologies).

miRNA target gene prediction and biological function analysis. The putative target genes of significant miRNAs were identified using the probability of interaction by target accessibility (PITA; http://genie.weizmann.ac.il), microRNAorg (http://www.microrna.org) and TargetScan (http://www.targetscan.org) target prediction systems. The Gene Ontologies (GOs) of the putative target genes were analyzed using the Database for Annotation, Visualization and Integrated Discovery (DAVID) Bioinformatics Resource 6.7 (http://david.abcc.ncifcrf.gov).

Statistical analysis. The data are presented as the mean \pm standard deviation. Statistical significance was calculated using Student's two-tailed t-test. Statistical analyses were conducted using Microsoft Excel 2013 (Microsoft Corporation, Redmond, WA, USA). $\mathrm{P}<0.01$ was considered to indicate a statistically significant difference, unless otherwise indicated.

\section{Results}

DHT induced cytotoxicity in nHDPCs. To determine whether DHT was associated with cell viability in nHDPCs, the present study analyzed the viability of DHT-treated nHDPCs after 24,48 , and $72 \mathrm{~h}$ using a WST-1 assay. Low concentrations of DHT $(<0.1 \mathrm{mM})$ demonstrated no significant toxicity in the nHDPCs at any of the time-points assessed. However, as shown in Fig. 1, cytotoxicity was significantly increased by $1 \mathrm{mM}$ DHT in the nHDPCs at every time-point assessed. Thus, it was determined that $1 \mathrm{mM}$ DHT induced cytotoxicity in the nHDPCs following exposure for $\geq 24 \mathrm{~h}$, which led to an exposure duration of $24 \mathrm{~h}$ being selected for use in the subsequent experiments.

DHT induces cell death and cell cycle arrest in nHDPCs. Previous experiments established that high levels of DHT 
induce apoptosis $(14,21)$. In agreement with the previous experiments (Fig. 2), the present study demonstrated that $1 \mathrm{mM}$ DHT increased cell death between 3.36 and $15.62 \%$ in the nHDPCs. In addition, the G1/G2 ratio was significantly increased by concentrations of DHT $>10^{-6} \mathrm{M}$, in a dose-dependent manner. The DHT-induced increment in G1/G2 ratio indicated that DHT induced G2 cell cycle arrest. Therefore, high-doses of DHT reduced cell viability through induction of cell death and G2 cell cycle arrest in the nHDPCs.

DHT increases ROS levels in $n H D P C s$. DHT can induce ROS in prostate cancer cell lines, which express the androgen receptor at a high level (14,22-24). Additionally, ROS are a key inducer of retinoblastoma-mediated senescence (25). As nHPDCs also express androgens at a high level (26), the present study investigated whether $1 \mathrm{mM}$ DHT induced ROS in these cells. The levels of ROS were determined using DCF-DA staining in untreated nHDPCs and in $1 \mathrm{mM}$ DHT-treated nHDPCs. As shown Fig. 3A, DHT significantly increased the level of ROS in the nHDPCs. In addition, the cellular effect underlying the effect of $1 \mathrm{mM}$ DHT in enhancing ROS levels in the nHDPCs was investigated. As shown in previous experiments in a prostate cell line (23), accumulated ROS induced senescence in the nHDPCs, as assessed by SA- $\beta$-gal activity (Fig. 3B).

As DHT induced growth arrest, cell death, cell cycle arrest, ROS production and senescence, comparative microarray analysis of miRNAs was performed to identify the miRNA signatures in the DHT-treated nHDPCs. Total RNA was extracted from the untreated nHDPCs and nHDPCs treated with $1 \mathrm{mM}$ DHT for $24 \mathrm{~h}$. The total RNA was labeled with $\mathrm{Cy} 3$ and hybridized to microarray-containing probes for 1,205 annotated miRNAs. The untreated cells were then compared with the $1 \mathrm{mM}$ DHT-treated nHDPCs, in which 55 miRNAs that were upregulated and 6 were downregulated, by more than two-fold (Table I). Among the five miRNAs significantly upregulated in the DHT-treated nHDPCs, the level of miR-3663-3p increased by 219.04 -fold, miR-485-3p by 200.81-fold, miR-7 by 173.64 -fold, miR-125a-3p by 154.55 -fold, and miR-4271 by 108 -fold. In addition, in the five miRNAs, which were significantly downregulated in the DHT-treated nHDPCs, the level of miR-450a decreased by -95.69 -fold, miR-1181 by -93.76 -fold, miR-3656 by -2.84 -fold, miR-4286 by -2.29 -fold and miR-370 by -2.24 -fold.

Subsequently, the putative target genes of DHT-regulated miRNAs were identified using the PITA, microRNAorg and Targetscan target prediction systems (Table II). A total of 587 putative target genes of the upregulated miRNAs and 140 putative target genes of the downregulated miRNAs were identified in PITA. Using microRNAorg, 488 putative target genes of upregulated miRNAs and 312 putative target genes of downregulated miRNAs were found, and 691 putative target genes of upregulated miRNAs and 219 putative target genes of downregulated miRNAs were identified using Targetscan. Of these, 339 were overlapping target genes of upregulated miRNAs and 111 were overlapping target genes of downregulated miRNAs in all three target prediction systems.

To investigate a association between the aforementioned effects of DHT and the putative miRNA target genes, GO analysis of each putative target gene was performed using DAVID. The genes were classified according to GO terms associated with the

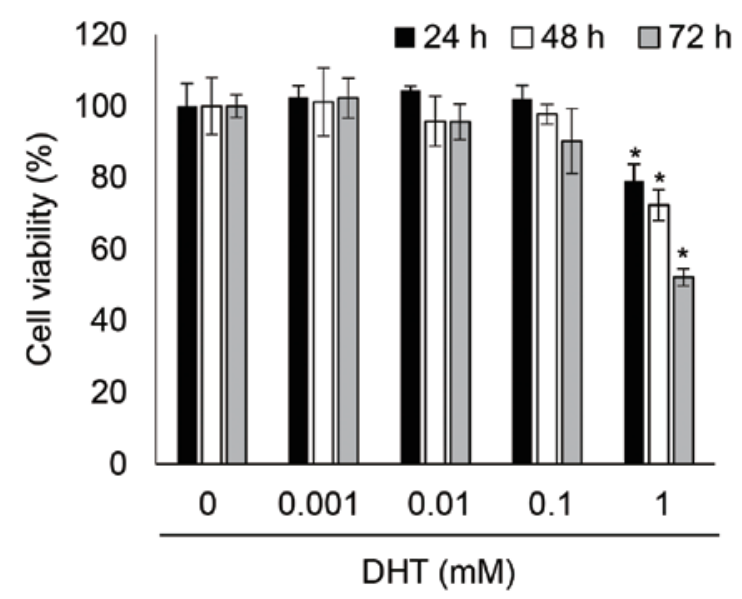

Figure 1. DHT induces cytotoxicity in nHDPCs. The nHDPCs were incubated with DHT at the indicated concentrations for 24,48 , and $72 \mathrm{~h}$ Following incubation, cytotoxicity was assessed based on measurements of cell viability using a WST-1 assay. The conversion of WST-1 to formazan was analyzed by measuring the optical density at $405 \mathrm{~nm}$. Data are presented as the mean \pm standard deviation of three independent experiments. Student's t-test was used to determine significance ( ${ }^{*} \mathrm{P}<0.01$ vs. control cells). nHDCs, normal human dermal papilla cells; DHT, $5 \alpha$-dihydrotestosterone; WST-1, water-soluble tetrazolium.

A

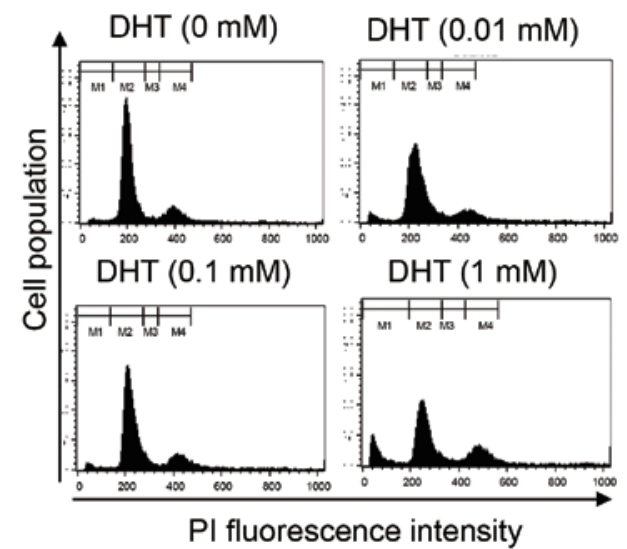

B

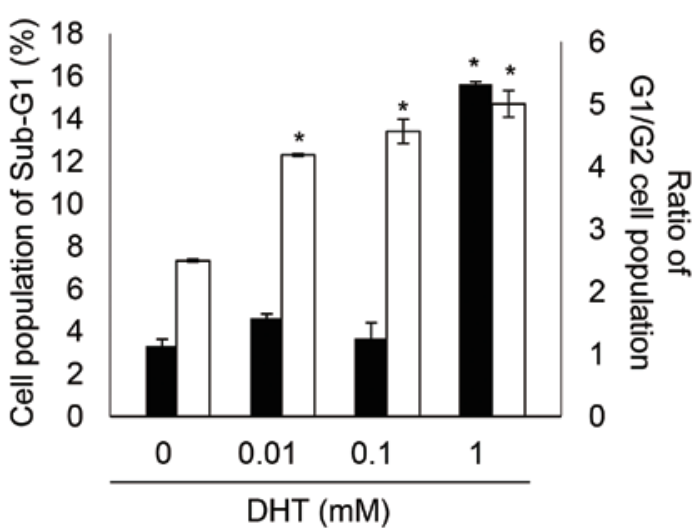

Figure 2. DHT induces cell cycle arrest and cell death in nHDPCs. (A) nHDPCs were incubated with the indicated concentrations of DHT for $24 \mathrm{~h}$, followed by PI staining of the DNA and flow cytometric analysis using the FL2 channel. Data are presented as the percentage of the gate. M1, sub-G1; M2, G1; M3, S; and M4, G2. (B) Proportion of cells in the sub-G1 (black bars) and the G1/G2 ratio (white bars). Data are expressed as the mean \pm standard deviation. Student's t-test was used to determine significance ( ${ }^{*} \mathrm{P}<0.01$ vs. control cells). nHDCs, normal human dermal papilla cells; DHT, $5 \alpha$-dihydrotestosterone; PI, propidium iodide. 
Table I. miRNAs exhibiting a $\geq 2$-fold change in expression following treatment of the nHDPCs with DHT.

\begin{tabular}{|c|c|c|c|}
\hline miRNA & $\begin{array}{c}\text { Fold } \\
\text { change }\end{array}$ & $\begin{array}{l}\text { Direction } \\
\text { of change }\end{array}$ & Chromosome \\
\hline hsa-let-7a* & 28.48 & Up & 9 \\
\hline hsa-miR-1181 & -93.76 & Down & 19 \\
\hline hsa-miR-1207-5p & 5.23 & Up & 8 \\
\hline hsa-miR-1225-5p & 3.08 & Up & 16 \\
\hline hsa-miR-1246 & 2.49 & Up & 2 \\
\hline hsa-miR-1249 & 35.73 & Up & 22 \\
\hline hsa-miR-125a-3p & 154.55 & Up & 19 \\
\hline hsa-miR-1268 & 2.38 & Up & 15 \\
\hline hsa-miR-128 & 35.55 & $\mathrm{Up}$ & 2 \\
\hline hsa-miR-1290 & 2.06 & Up & 1 \\
\hline hsa-miR-132 & 40.88 & Up & 17 \\
\hline hsa-miR-134 & 90.23 & Up & 14 \\
\hline hsa-miR-135a* & 45.73 & Up & 3 \\
\hline hsa-miR-138-2* & 52.92 & $\mathrm{Up}$ & 16 \\
\hline hsa-miR-146a & -2.01 & Down & 5 \\
\hline hsa-miR-148b & 50.96 & Up & 12 \\
\hline hsa-miR-150* & 98.34 & Up & 19 \\
\hline hsa-miR-1539 & 40.93 & Up & 18 \\
\hline hsa-miR-154* & -2.24 & Down & 14 \\
\hline hsa-miR-17* & 60.48 & Up & 13 \\
\hline hsa-miR-1915 & 3.07 & Up & 10 \\
\hline hsa-miR-197 & 84.06 & Up & 1 \\
\hline hsa-miR-1973 & 2.20 & Up & 4 \\
\hline hsa-miR-202 & 35.08 & Up & 10 \\
\hline hsa-miR-28-5p & 36.51 & $\mathrm{Up}$ & 3 \\
\hline hsa-miR-324-5p & 36.40 & Up & 17 \\
\hline hsa-miR-3613-3p & 78.20 & Up & 13 \\
\hline hsa-miR-3646 & 50.21 & Up & 20 \\
\hline hsa-miR-3651 & 2.98 & Up & 9 \\
\hline hsa-miR-3656 & -2.84 & Down & 11 \\
\hline hsa-miR-3663-3p & 219.04 & Up & 10 \\
\hline hsa-miR-369-3p & 36.36 & Up & 14 \\
\hline hsa-miR-370 & 40.16 & Up & 14 \\
\hline hsa-miR-371-5p & 78.83 & Up & 19 \\
\hline hsa-miR-378 & 48.73 & Up & 5 \\
\hline hsa-miR-409-5p & 44.22 & Up & 14 \\
\hline hsa-miR-423-5p & 49.28 & Up & 17 \\
\hline hsa-miR-4270 & 36.98 & Up & 3 \\
\hline hsa-miR-4271 & 108.00 & Up & 3 \\
\hline hsa-miR-4281 & 2.81 & Up & 5 \\
\hline hsa-miR-4286 & -2.29 & Down & 8 \\
\hline hsa-miR-4291 & 53.23 & Up & 9 \\
\hline hsa-miR-4299 & 2.14 & Up & 11 \\
\hline hsa-miR-431 & 35.70 & Up & 14 \\
\hline hsa-miR-431* & 25.62 & Up & 14 \\
\hline hsa-miR-4317 & 38.79 & Up & 18 \\
\hline hsa-miR-4327 & 34.79 & Up & 21 \\
\hline hsa-miR-450a & -95.69 & Down & $\mathrm{X}$ \\
\hline hsa-miR-483-5p & 39.06 & Up & 11 \\
\hline hsa-miR-485-3p & 200.81 & Up & 14 \\
\hline hsa-miR-500a & 2.30 & Up & $\mathrm{X}$ \\
\hline hsa-miR-513a-5p & 2.68 & Up & $\mathrm{X}$ \\
\hline hsa-miR-513b & 47.72 & Up & $X$ \\
\hline
\end{tabular}

Table I. Continued.

\begin{tabular}{lrcc}
\hline miRNA & $\begin{array}{c}\text { Fold } \\
\text { change }\end{array}$ & $\begin{array}{c}\text { Direction } \\
\text { of change }\end{array}$ & Chromosome \\
\hline hsa-miR-550a & 18.95 & $\mathrm{Up}$ & 7 \\
hsa-miR-572 & 39.29 & $\mathrm{Up}$ & 4 \\
hsa-miR-630 & 3.53 & $\mathrm{Up}$ & 15 \\
hsa-miR-642b & 105.36 & $\mathrm{Up}$ & 19 \\
hsa-miR-7 & 173.64 & $\mathrm{Up}$ & 9 \\
hsa-miR-762 & 5.26 & $\mathrm{Up}$ & 16 \\
hsa-miR-770-5p & 56.99 & $\mathrm{Up}$ & 14 \\
hsa-miR-874 & 62.43 & $\mathrm{Up}$ & 5
\end{tabular}

The direction of change is relative to the control. miRNA/miR, microRNA; Up, upregulated; Down, downregulated.

A

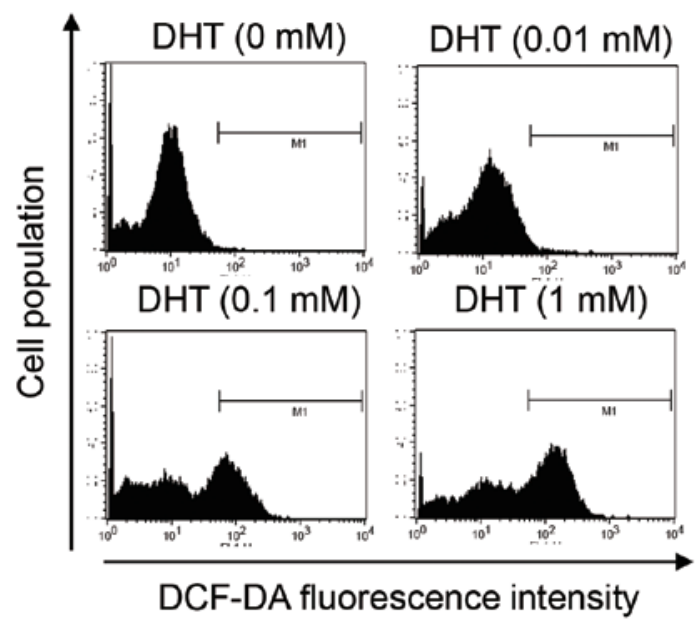

B

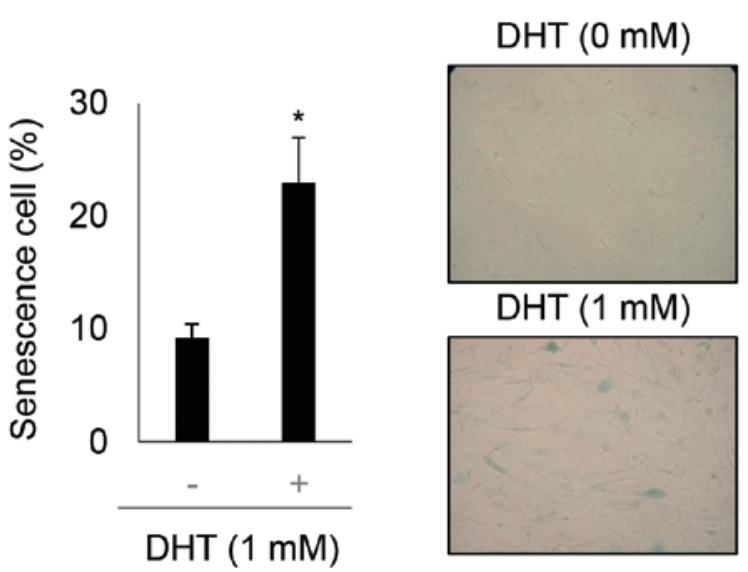

Figure 3. DHT induces intracellular ROS and senescence in nHDPCs. (A) Flow cytometric analysis of ROS levels. The nHDPCs were incubated with the indicated concentrations of DHT for $24 \mathrm{~h}$, followed by DCF-DA staining and flow cytometric analysis using the FL1 channel. Data are presented as the percentage of the gate (M1). (B) Staining and quantification of senescent cells. The nHDPCs were fixed and stained with X-gal under acidic conditions to detect senescent cells (blue) by measuring senescence-associated $\beta$-galactosidase activity (magnificaiton, $x 100$ ). Data represent the mean \pm standard deviation of three independent experiments. Student's t-test was used to determine significance (" $\mathrm{P}<0.01$ vs. control cells). nHDCs, normal human dermal papilla cells; DHT, $5 \alpha$-dihydrotestosterone; DCF-DA, 2'7'-dichlorofluorescein diacetate; ROS, reactive oxygen species. 
Table II. Number of significant miRNA targets using three prediction databases.

\begin{tabular}{lcc}
\hline Database & Target miRNAs (n) & Overlapping miRNAs in all three databases (n) \\
\hline Upregulated target miRNAs & & 339 \\
Targetscan & 691 & \\
PITA & 587 & 111 \\
microRNAorg & 488 & \\
Downregulated target miRNAs & & \\
Targetscan & 219 & \\
PITA & 140 & 312 \\
microRNAorg & & \\
\hline
\end{tabular}

miRNA, microRNA; PITA, probability of interaction by target accessibility.

Table III. Genes grouped according to the GO terms, associated with the effects of $5 \alpha$-dihydrotestosterone.

A, Antioxidant-associated genes

\begin{tabular}{llcc}
\hline Accession No. & \multicolumn{1}{c}{ GO term } & Upregulated (n) & Downregulated (n) \\
\hline GO:0006733 & Oxidoreduction coenzyme metabolic process & 3 & 0 \\
GO:0006979 & Response to oxidative stress & 5 & 2 \\
GO:0042542 & Response to hydrogen peroxide & 2 & 0 \\
GO:0015980 & Energy derivation by oxidation of organic compounds & 0 & 3 \\
GO:0055114 & Oxidation reduction & 6 & 6 \\
\hline
\end{tabular}

B, Apoptosis and cell death-associated genes

Accession No.

GO term

Upregulated (n)

Downregulated (n)

GO:0006916

GO:0008624

GO:0042981

GO:0043066

GO:0043065

GO:0006917

GO:0006915

GO:0043067

GO:0010941

GO:0043069

GO:0060548

GO:0043068

GO:0010942

GO:0012502

GO:0008219

GO:0016265

GO:0012501

Anti-apoptosis
Induction of apoptosis by extracellular signals
Regulation of apoptosis
Negative regulation of apoptosis
Positive regulation of apoptosis
Induction of apoptosis
Apoptosis
Regulation of programmed cell death
Regulation of cell death
Negative regulation of programmed cell death
Negative regulation of cell death
Positive regulation of programmed cell death
Positive regulation of cell death
Induction of programmed cell death
Cell death
Death
Programmed cell death

Anti-apoptosis

Induction of apoptosis by extracellular signals

Regulation of apoptosis

Negative regulation of apoptosis

Apoptosis

Regulation of programmed cell death

Regulation of cell death

Negative regulation of programmed cell death

Negative regulation of cell death

Positive regulation of programmed cell death

Positive regulation of cell death

Induction of programmed cell death

Death

Programmed cell death

4
0
7
4
2
0
5
4
4
0
0
2
2
0
6
6
5

C, Proliferation and cell growth-associated genes

\begin{tabular}{llrl}
\hline Accession No. & \multicolumn{1}{c}{ GO term } & Upregulated (n) & Downregulated (n) \\
\hline GO:0008283 & Cell proliferation & 9 & 3 \\
GO:0008284 & Positive regulation of cell proliferation & 8 & 5 \\
GO:0042127 & Regulation of cell proliferation & 12 & 7 \\
GO:0008285 & Negative regulation of cell proliferation & 4 & 3 \\
GO:0030308 & Negative regulation of cell growth & 3 & 0 \\
\hline
\end{tabular}


Table III. Continued.

\begin{tabular}{llcc}
\hline Accession No. & \multicolumn{1}{c}{ GO term } & Upregulated (n) & Downregulated (n) \\
\hline GO:0040008 & Regulation of growth & 7 & 4 \\
GO:0048638 & Regulation of developmental growth & 2 & 0 \\
GO:0045926 & Negative regulation of growth & 3 & 0 \\
GO:0001558 & Regulation of cell growth & 4 & 2 \\
GO:0045927 & Positive regulation of growth & - & 2 \\
GO:0040007 & Growth & 3 & 0 \\
\hline
\end{tabular}

$\mathrm{D}$, Aging-associated genes

\begin{tabular}{llcc}
\hline Accession No. & GO term & Upregulated (n) & Downregulated (n) \\
\hline GO:0007568 & Aging & 3 & 0 \\
\hline
\end{tabular}

E, Cell cycle-associated genes

\begin{tabular}{llrl}
\hline Accession No. & \multicolumn{1}{c}{ GO term } & Upregulated (n) & Downregulated (n) \\
\hline GO:0051726 & Regulation of cell cycle & 13 & 0 \\
GO:0045786 & Negative regulation of cell cycle & 5 & 0 \\
GO:0051327 & M phase of meiotic cell cycle & 4 & 0 \\
GO:0051321 & Meiotic cell cycle & 4 & 2 \\
GO:0045930 & Negative regulation of mitotic cell cycle & 2 & 0 \\
GO:0010948 & Negative regulation of cell cycle process & 2 & 0 \\
GO:0007346 & Regulation of mitotic cell cycle & 4 & 0 \\
GO:0022403 & Cell cycle phase & 8 & 2 \\
GO:0010564 & Regulation of cell cycle process & 3 & 14 \\
GO:0007049 & Cell cycle & 9 & 4 \\
GO:0022402 & Cell cycle process & 6 & 4 \\
GO:0000278 & Mitotic cell cycle & 2 & 0 \\
GO:0000075 & Cell cycle checkpoint & 3 & 0 \\
GO:0000087 & M phase of mitotic cell cycle & & 0 \\
\hline
\end{tabular}

GO, Gene Ontology.

five effects of DHT and the number of putative target genes associated with each GO term were counted. As shown in Table III, the putative target genes of the uppregulated and downregulated miRNAs were associated with five antioxidant-associated GO terms, 17 apoptosis and cell death-associated terms, 11 proliferation and cell growth-associated terms, 1 age associated term and 14 cell cycle-associated GO terms. The miRNAs and their putative target genes are shown in Table IV. Overall, these results demonstrated that DHT exerted negative effects, which were associated with an alteration in cellular miRNA expression profiles.

\section{Discussion}

The results of the present study provided evidence that DHT induced growth arrest, cell death, cell cycle arrest, ROS production and senescence in nHDPCs. In the hair follicle, DHT is produced by $5 \alpha$-reductase and it accumulates, which induces androgenetic alopecia through DHT-mediated cell death and decreased growth rate (27-29). As shown in Figs. 1 and 2, 1 mM DHT repressed cell growth by inducing cell cycle arrest and cell death. In a previous report, activation of the androgen receptor provoked ROS-mediated senescence $(30,31)$. As shown in Fig. 3, measurement of ROS revealed that $1 \mathrm{mM}$ DHT significantly elevated the levels of ROS in the nHDPCs. In the nHDPCs, which exhibited increased activity of the androgen receptor by DHT, $1 \mathrm{mM}$ DHT significantly increased the percentage of senescent cells (Fig. 3B). Specifically, an association was observed between the effects of DHT and the regulation of miRNAs by DHT. Using miRNA microarray analysis, 61 miRNAs (55 upregulated and 6 downregulated) were identified, in which the miRNA levels were increased of decreased by more than two-fold by DHT in the nHDPCs (Table I). One of these, miRNA-125a-3p has been demonstrated as a repressor of cell proliferation and migration through targeting Fyn (32). In addition, miR-485-5p (39.06-fold increase) inhibits cell growth and migration in breast cancer cell lines (33), whereas miRNA-7 regulates the mammalian target of rapamycin and phosphoinositide 3-kinase/Akt pathways, 
Table IV. Target genes of significantly regulated miRNAs in DHT-treated nHDPCs.

A, Targets of up-regulated miRNAs

\begin{tabular}{|c|c|c|c|c|c|}
\hline miRNA & Antioxidant & $\begin{array}{l}\text { Apoptosis and } \\
\text { cell death }\end{array}$ & $\begin{array}{l}\text { Proliferation } \\
\text { and cell growth }\end{array}$ & Aging & Cell cycle \\
\hline $3663-3 p$ & $\begin{array}{l}\text { GAPDHS, } \\
\text { NDUFA } 8, \\
\text { GAPDH, } \\
\text { DEGS2, DCXR }\end{array}$ & CARD9, ADA & FOXS1, ENO1 & - & - \\
\hline a485-3p & $\begin{array}{l}\text { APOA4, PRDX1, } \\
\text { NDUFAB1, } \\
\text { NQO2 }\end{array}$ & GNRH1, PRDX1 & - & - & - \\
\hline a7 & $\begin{array}{l}\text { CYP11A1, UCP2, } \\
\text { NQO2 NEIL1, } \\
\text { BCKDHA, FADS3, } \\
\text { ALKBH2 }\end{array}$ & $\begin{array}{l}\text { DAPL1, } \\
\text { CASP12, DDX41, } \\
\text { DAPK3, BCL2L12, } \\
\text { CRYAA, CSTB, } \\
\text { INHA }\end{array}$ & $\begin{array}{l}\text { BMP10, LBX1, } \\
\text { INHA, IL34, } \\
\text { CKLF, SLC3A2, } \\
\text { ENO3, BDKRB1, } \\
\text { OGFR, }\end{array}$ & - & $\begin{array}{l}\text { RNF167, INHA, } \\
\text { CDC37, CRYAA }\end{array}$ \\
\hline${ }^{a} 125-3 p$ & $\begin{array}{l}\text { BCKDHA, } \\
\text { NDUFS7, FTMT, } \\
\text { PLOD3, TH, } \\
\text { COX6B1, HGD, } \\
\text { AKR1C1 }\end{array}$ & $\begin{array}{l}\text { PYCARD, } \\
\text { LGALS12, TGFB1, } \\
\text { LRDD, GML, ADA }\end{array}$ & $\begin{array}{l}\text { BDKRB1, } \\
\text { SCGB3A1, } \\
\text { NPPA, TGFB1, } \\
\text { ENO1, E4F1, } \\
\text { FTMT, AGER, } \\
\text { ADA, FGF6, } \\
\text { PRG4, GML }\end{array}$ & $\begin{array}{l}\text { AGER, } \\
\text { ADA, } \\
\text { TGFB1 }\end{array}$ & $\begin{array}{l}\text { TUBB2A, } \\
\text { SPAG5, PKMYT1, } \\
\text { CDC20, TGFB1, } \\
\text { E4F1, GML, } \\
\text { CDK5RAP3 } \\
\text { PARD6A, GPS2 }\end{array}$ \\
\hline a4271 & $\begin{array}{l}\text { BCKDHA, NDUFS7, } \\
\text { NDUFB11, NDUFB10, } \\
\text { HAO2, NDUFS8, } \\
\text { FADS3, FDX1L, } \\
\text { ALOX12B, IL4I1, } \\
\text { NSDHL }\end{array}$ & $\begin{array}{l}\text { GZMM, DAPL1, } \\
\text { LRDD, ATP2A1, } \\
\text { MGC } 29506\end{array}$ & $\begin{array}{l}\text { SSTR4, PRTN3, } \\
\text { GHRH, ILK, } \\
\text { PYY, PRSS2, } \\
\text { BARHL2, } \\
\text { OGFR, ENO1 }\end{array}$ & - & $\begin{array}{l}\text { BGLAP, } \\
\text { PKMYT1, ILK }\end{array}$ \\
\hline
\end{tabular}

$\mathrm{B}$, Targets of down-regulated miRNAs

\begin{tabular}{|c|c|c|c|c|c|}
\hline miRNA & Antioxidant & $\begin{array}{l}\text { Apoptosis and } \\
\text { cell death }\end{array}$ & $\begin{array}{c}\text { Proliferation } \\
\text { and cell growth }\end{array}$ & Aging & Cell cycle \\
\hline a $450 \mathrm{a}$ & $\begin{array}{l}\text { UQCRH, } \\
\text { ALKBH2 }\end{array}$ & - & - & - & - \\
\hline${ }^{\mathrm{a}} 1181$ & - & - & - & - & - \\
\hline a3656 & - & $\begin{array}{l}\text { CARD9, INS, } \\
\text { TMEM102, SFN, } \\
\text { ATP2A1 }\end{array}$ & $\begin{array}{l}\text { INS, SFN, } \\
\text { SCGB3A1, } \\
\text { VGF }\end{array}$ & - & INS, SFN \\
\hline a 428 & $\begin{array}{l}\text { NDUFB11, } \\
\text { NMRAL1, } \\
\text { FDX1L }\end{array}$ & $\begin{array}{l}\text { AARS, MUC5AC, } \\
\text { DAPK3, CDK5, } \\
\text { TGFB1, PROC, } \\
\text { MIF, LRDD, TBRG4 }\end{array}$ & - & $\begin{array}{l}\text { FANCG, CDK5, } \\
\text { SERTAD1, TGFB1, } \\
\text { TBRG4, PARD6A }\end{array}$ & - \\
\hline${ }^{\mathrm{a}} 154$ & - & $\begin{array}{l}\text { IFIH1, CASP12, } \\
\text { PF4, PRDX1 }\end{array}$ & $\begin{array}{l}\text { VTI1B, PRDX1, } \\
\text { RARRES3, } \\
\text { GNL3 }\end{array}$ & - & - \\
\hline
\end{tabular}

ahsa-miR. miR/miRNA, microRNA.

and targets Bcl-2, X-linked inhibitor of apoptosis protein and ETS2 repressor factor, which affect cell growth and the repres- sion of intrinsic apoptosis (34-39). Furthermore, the present study predicted the target genes of DHT-regulated miRNAs 
and performed GO analysis of potential target genes using the DAVID bioinformatics resources. A correlation was found between DHT-induced alterations in miRNA expression profiles and DHT-induced cellular effects, by grouping the target genes, according to GO terms, with five biological processes, which impacted in DHT-treated cells (Tables II and III). The results revealed that the DHT-induced alteration of the miRNA profile was associated with the aforementioned cellular effects of DHT, of induced cell growth, cell cycle arrest, cell death, ROS induction and senescence.

In conclusion, the present study demonstrated that DHT induced growth arrest, cell death, cell cycle arrest, ROS production and senescence by upregulating and downregulating the expression of DHT-specific miRNAs in nHDPCs. These findings support the hypothesis that miRNA regulation is involved in DHT-induced androgenetic alopecia.

\section{Acknowledgements}

This study was supported by Konkuk University in 2013.

\section{References}

1. Yazdan P: Update on the genetics of androgenetic alopecia, female pattern hair loss, and alopecia areata: Implications for molecular diagnostic testing. Semin Cutan Med Surg 31: 258-266, 2012

2. Alsantali A and Shapiro J: Androgens and hair loss. Curr Opin Endocrinol Diabetes Obes 16: 246-253, 2009.

3. Canguven O and Burnett AL: The effect of 5 alpha-reductase inhibitors on erectile function. J Androl 29: 514-523, 2008.

4. Rove KO, Debruyne FM, Djavan B, Gomella LG, Koul HK, Lucia MS, Petrylak DP, Shore ND, Stone NN and Crawford ED: Role of testosterone in managing advanced prostate cancer. Urology 80: 754-762, 2012.

5. Hillier SG and Tetsuka M: Role of androgens in follicle maturation and atresia. Baillieres Clin Obstet Gynaecol 11: 249-260, 1997.

6. McElwee KJ, Kissling S, Wenzel E, Huth A and Hoffmann R: Cultured peribulbar dermal sheath cells can induce hair follicle development and contribute to the dermal sheath and dermal papilla. J Invest Dermatol 121: 1267-1275, 2003.

7. Yang CC and Cotsarelis G: Review of hair follicle dermal cells. J Dermatol Sci 57: 2-11, 2010.

8. Tang L, Bernardo O, Bolduc C, Lui H, Madani S and Shapiro J: The expression of insulin-like growth factor 1 in follicular dermal papillae correlates with therapeutic efficacy of finasteride in androgenetic alopecia. J Am Acad Dermatol 49: 229-233, 2003.

9. Stenn KS, Combates NJ, Eilertsen KJ, Gordon JS, Pardinas JR, Parimoo S and Prouty SM: Hair follicle growth controls. Dermatol Clin 14: 543-558, 1996.

10. Peus D and Pittelkow MR: Growth factors in hair organ development and the hair growth cycle. Dermatol Clin 14: 559-572, 1996.

11. Stenn KS and Paus R: Controls of hair follicle cycling. Physiol Rev 81: 449-494, 2001.

12. Ferraris C, Cooklis M, Polakowska RR and Haake AR: Induction of apoptosis through the PKC pathway in cultured dermal papilla fibroblasts. Exp Cell Res 234: 37-46, 1997.

13. Kwack MH, Sung YK, Chung EJ, Im SU, Ahn JS, Kim MK and Kim JC: Dihydrotestosterone-inducible dickkopf 1 from balding dermal papilla cells causes apoptosis in follicular keratinocytes. J Invest Dermatol 128: 262-269, 2008.

14. Winiarska A, Mandt N, Kamp H, Hossini A, Seltmann H, Zouboulis CC and Blume-Peytavi U: Effect of 5alpha-dihydrotestosterone and testosterone on apoptosis in human dermal papilla cells. Skin Pharmacol Physiol 19: 311-321, 2006.

15. Ambros V, Bartel B, Bartel DP, Burge CB, Carrington JC, Chen X, Dreyfuss G, Eddy SR, Griffiths-Jones S, Marshall M, et al: A uniform system for microRNA annotation. RNA 9: 277-279, 2003.

16. Valencia-Sanchez MA, Liu J, Hannon GJ and Parker R: Control of translation and mRNA degradation by miRNAs and siRNAs. Genes Dev 20: 515-524, 2006.
17. Ha TY: MicroRNAs in Human Diseases: From Cancer to Cardiovascular Disease. Immune Netw 11: 135-154, 2011.

18. Andl T, Murchison EP, Liu F, Zhang Y, Yunta-Gonzalez M, Tobias JW, Andl CD, Seykora JT, Hannon GJ and Millar SE: The miRNA-processing enzyme dicer is essential for the morphogenesis and maintenance of hair follicles. Curr Biol 16: 1041-1049, 2006.

19. Bae S, Lee EJ, Lee JH, Park IC, Lee SJ, Hahn HJ, Ahn KJ, An S, An IS and Cha HJ: Oridonin protects $\mathrm{HaCaT}$ keratinocytes against hydrogen peroxide-induced oxidative stress by altering microRNA expression. Int J Mol Med 33: 185-193, 2014.

20. Kim YJ,Cha HJ,Nam KH, Yoon Y,Lee Hand An S: Centella asiatica extracts modulate hydrogen peroxide-induced senescence in human dermal fibroblasts. Exp Dermatol 20: 998-1003, 2011.

21. Simões VL, Alves MG, Martins AD, Dias TR, Rato L, Socorro S and Oliveira PF: Regulation of apoptotic signaling pathways by $5 \alpha$-dihydrotestosterone and $17 \beta$-estradiol in immature rat Sertoli cells. J Steroid Biochem Mol Biol 135: 15-23, 2013.

22. Mirochnik Y, Veliceasa D, Williams L, Maxwell K, Yemelyanov A, Budunova I and Volpert OV: Androgen receptor drives cellular senescence. PLoS One 7: e31052, 2012.

23. Mehraein-Ghomi F, Lee E, Church DR, Thompson TA, Basu HS and Wilding G: JunD mediates androgen-induced oxidative stress in androgen dependent $\mathrm{LNCaP}$ human prostate cancer cells. Prostate 68: 924-934, 2008.

24. Ruizeveld de Winter JA, Trapman J, Vermey M, Mulder E, Zegers ND and van der Kwast TH: Androgen receptor expression in human tissues: An immunohistochemical study. J Histochem Cytochem 39: 927-936, 1991.

25. Takahashi A, Ohtani N, Yamakoshi K, Iida S, Tahara H, Nakayama K, Nakayama KI, Ide T, Saya H and Hara E: Mitogenic signalling and the p16INK4a-Rb pathway cooperate to enforce irreversible cellular senescence. Nat Cell Biol 8: 1291-1297, 2006.

26. Hodgins MB, Choudhry R, Parker G, Oliver RF, Jahoda CA, Withers AP, Brinkmann AO, van der Kwast TH, Boersma WJ, Lammers KM, et al: Androgen receptors in dermal papilla cells of scalp hair follicles in male pattern baldness. Ann NY Acad Sci 642: 448-451, 1991.

27. Eicheler W, Happle R and Hoffmann R: 5 alpha-reductase activity in the human hair follicle concentrates in the dermal papilla. Arch Dermatol Res 290: 126-132, 1998.

28. Trüeb RM: Molecular mechanisms of androgenetic alopecia. Exp Gerontol 37: 981-990, 2002.

29. Inui S and Itami S: Molecular basis of androgenetic alopecia: From androgen to paracrine mediators through dermal papilla. J Dermatol Sci 61: 1-6, 2011.

30. Mirochnik Y, Veliceasa D, Williams L, Maxwell K, Yemelyanov A, Budunova I and Volpert OV: Androgen receptor drives cellular senescence. PLoS One 7: e31052, 2012.

31. Colavitti R and Finkel T: Reactive oxygen species as mediators of cellular senescence. IUBMB Life 57: 277-281, 2005.

32. Ninio-Many L, Grossman H, Shomron N, Chuderland D and Shalgi R: microRNA-125a-3p reduces cell proliferation and migration by targeting Fyn. J Cell Sci 126: 2867-2876, 2013.

33. Anaya-Ruiz M, Bandala C and Perez-Santos JL: miR-485 acts as a tumor suppressor by inhibiting cell growth and migration in breast carcinoma T47D cells. Asian Pac J Cancer Prev 14: 3757-3760, 2013.

34. Wang Y, Liu J, Liu C, Naji A and Stoffers DA: MicroRNA-7 regulates the mTOR pathway and proliferation in adult pancreatic $\beta$-cells. Diabetes 62: 887-895, 2013.

35. Fang Y, Xue JL, Shen Q, Chen J and Tian L: MicroRNA-7 inhibits tumor growth and metastasis by targeting the phosphoinositide 3-kinase/Akt pathway in hepatocellular carcinoma. Hepatology 55: 1852-1862, 2012.

36. Xiong S, Zheng Y, Jiang P, Liu R, Liu X and Chu Y: MicroRNA-7 inhibits the growth of human non-small cell lung cancer A549 cells through targeting BCL-2. Int J Biol Sci 7: 805-814, 2011.

37. Chou YT, Lin HH, Lien YC, Wang YH, Hong CF, Kao YR, Lin SC, Chang YC, Lin SY, Chen SJ, et al: EGFR promotes lung tumorigenesis by activating miR-7 through a Ras/ERK/Myc pathway that targets the Ets2 transcriptional repressor ERF. Cancer Res 70: 8822-8831, 2010.

38. Jiang L, Liu X, Chen Z, Jin Y, Heidbreder CE, Kolokythas A, Wang A, Dai Y and Zhou X: MicroRNA-7 targets IGF1R (insulin-like growth factor 1 receptor) in tongue squamous cell carcinoma cells. Biochem J 432: 199-205, 2010.

39. Liu S, Zhang P, Chen Z, Liu M, Li X and Tang H: MicroRNA-7 downregulates XIAP expression to suppress cell growth and promote apoptosis in cervical cancer cells. FEBS Lett 587: 2247-2253, 2013. 